\title{
POLA ASUH GRANDPARENTING DALAM MEMBENTUK KEPRIBADIAN ANAK USIA 4-6 TAHUN
}

Fitri Handayani ${ }^{1}$, Asiyah ${ }^{2}$, Septi Fitriana ${ }^{3}$

Prodi PIAUD, IAIN Bengkulu

Fitrihandayanibk188@gmail.com, asiyah2710@gmail.com, septifitriana@iainbengkulu.ac.id

\section{DOI: $10.46781 /$ al-abyadh.v4i2.265}

\begin{abstract}
Abstrak
Model pengasuhan yang dilakukan oleh kakek dan nenek disebut Grandparenting. Anak yang seharusnya menjadi tanggung jawab orang tua kemudian [engasuhan dialihkan kepada kakek dan nenek karena beberapa faktor antara lain orang tua terlalu sibuk dengan pekerjaan, kondisi ekonomi yang tidak stabil, dan kurangnya kepercayaan pada orang asing yang bukan saudara. Di Kelurahan RT/007 RW/002, Dusun Besar, Kota Bengkulu terhadap 7 keluarga yang mewariskan pola asuh kepada kakek dan nenek. Jika diterapkan, bentuk pola asuh ini akan berdampak pada kepribadian anak. Penelitian ini merupakan penelitian deskriptif kualitatif untuk mengidentifikasi dan mendeskripsikan hasil di lapangan. Pengumpulan data dilakukan melalui tiga cara yaitu: observasi, wawancara dan dokumentasi. Adapun hasil Model pengasuhan Grandparenting yaitu terdapat keluarga menerapkan pola asuh demokratis sebanyak 4 keluarga dan 3 lainnya menerapkan model permisif. Pada kepribadian anak terdapat 3 orang anak berkepribadian sanguin, 1 orang anak berkepribadian flegmatik, 1 orang anak berkepribadian kolerik dan anak berkepribadian asertif sebanyak 1 orang.
\end{abstract}

Kata kunci: Pola Asuh Grandparenting, Kepribadian Anak Usia 4-6 Tahun

\section{GRANDPARENTING PATTERNS IN FORMING THE PERSONALITY OF CHILDREN AGED 4-6 YEARS}

Fitri Handayani ${ }^{1}$, Asiyah $^{2}$, Septi Fitriana ${ }^{3}$

Prodi PIAUD, IAIN Bengkulu

Fitrihandayanibk188@gmail.com, asiyah2710@gmail.com, septifitriana@iainbengkulu.ac.id

\begin{abstract}
The parenting model carried out by grandparents is called Grandparenting. Children who should be the responsibility of parents are then transferred to grandparents due to several factors, including parents being too busy with work, unstable economic conditions, and lack of trust in strangers who are not relatives. In Kelurahan RT/007 RW/002, Dusun Besar, Bengkulu City, 7 families passed on their parenting styles to their grandparents. If applied, this parenting will have an impact on the shape of the child's personality. This research is a qualitative descriptive study to identify and describe the results in the field. Data was collected in three ways, namely: observation, interviews and documentation. The results of the Grandparenting Parenting Model are that there are 4 families applying democratic parenting and 3 others applying the permissive model. In the child's personality, there are 3 children with sanguine personality, 1 child with phlegmatic personality, 1 child with choleric personality, and 1 child with assertive personality as many as 1 person.
\end{abstract}

Keywords: Grandparenting, Personality of 4-6 Years Old Children

\author{
Al Abyadh \\ ISSN: $2620-7265$ \\ E-ISSN: 2775-7080
}




\section{Pendahuluan}

Pada hakekatnya pendidikan pada anak usia dini merupakan pendidikan yang diselenggarakan dalam rangka memfasilitasi tumbuh kembang anak yang dilakukan secara utuh atau yang menitikberatkan pada setiap aspek perkembangan pada anak. (Suyadi, 2014) Pendidikan pada anak usia dini memiliki ciri khas tersendiri dan berbeda dengan pendidikan pada usia yang lebih lanjut, bahkan dengan usia yang sebaya (Mulyasa, 2017). Pada UU No 20 Tahun 2003 tentang Sistem Pendidikan Nasional menerangkan bahwa ada tiga jalur pemyelenggaraan pendidikan di Indonesia yaitu jalur pendidikan formal, nonformal, dan jalur pendidikan informal. Pasal 13 ayat $1 \mathrm{UU}$ No. 20 Tahun 2003 menjelaskan bahwa ketiga jalur tersebut saling melengkapi dan memperkaya. (Mennteri Pendidikan Nasional, 2003).

Pada Penelitian ini, peneliti terfokus kepada pendidikan informal. Pendidikan informal diselenggarakan secara terpisah, sepenuhnya menjadi tanggung jawab orang tua dan siswa sebagai individu tidak dalam bentuk kelompok (Adiwikarta, 2016).

Secara Psikologis, sekelompok orang yang hidup bersama, berbagi atau hidup bersama dan setiap anggota akan merasa terhubung, semangat yang akan memicu saling minat, pengaruh dan saling menyerah disebut sebagai keluarga. Sedangkan secara Pedagogis, keluarga ialah satu persekutuan hidup antara sepasangan manusia yang diikat melalui pernikahan dengan tujuan untuk saling menyempurnakan diri serta dijalani dengan kasih sayang (Shochib, 2018). (Shochib, 2018).

Sebagai lembaga pendidikan, orang tua memiliki beberapa fungsi diantaranya adalah membimbing dan mendidik anak selama di rumah serta mendukung pendidikan anak di sekolah (Dachlan et al., 2019). Kepribadian orang tua wajib menggambarkan sikap dan perilaku yang luhur. Islam mengajarkan agar para orang tua selalu mengajarkan hal-hal baik pada anaknya (Umar dan Sulo, 2000) Karena peran orang tua dan keluarga merupakan tanggung jawab tertinggi sejak anaknya dilahirkan sampai anak tumbuh dewasa. Pengasuhan tidak boleh membiarkan anak mengalami pertumbuhan dan perkembangan tanpa adanya bimbingan dan pengawasan dari orang tua. Oleh karena itu, dibutuhkan penyuluhan untuk memberikan bimbingan secara jelas dalam membentuk kepribadian anak mengikuti jalan yang benar (Suyadi dan Ulfah, 2015).

Pengasuhan langsung diajarkan dari saat pertama kali dimana anak belajar untuk makan, bersih-bersih, disiplin, bermain atau bergaul dengan anak yang lain, dll. Jika stereotip yang dianut orang tua salah, maka akan terbentuk sebuah perilaku yang tidak baik, bahkan dapat memperburuk perilaku pada anak. Masing-masing anggota keluarga memiliki peran yang jelas yaitu ayah adalah kepala keluarga serta yang mencari nafkah sedangkan ibu yang melakukan pekerjaan rumah. Namun, ada beragam kondisi keluarga yang ada di Indonesia, dimana banyak orang tua bekerja untuk dapat meningkatkan pendapatannya sehingga hanya memiliki sedikit waktu yang digunakan dalam memantau tumbuh kembang anaknya.

Pola asuh terbentuk dari dua suku kata yaitu kata pola dan kata asuh. Berdasarkan Kamus Besar Bahasa Indonesia (KBBI), Pola dapat didefinisikan menjadi sebuah model, corak, cara kerja, bentuk atau struktur yang tetap dan sebuah sistem. Pengasuhan secara Etimologi terbentuk dari kata "asuh" berarti memimpin, membimbing, mengelola, sehingga dapat disimpulkan bahwa "pengasuh" diartikan sebagai seorang yang diberikan tanggung jawab untuk melakukan bimbimbingan, memimpin ataupun mengelola. Adapun pengasuhan yang dimaksud ialah mengasuh anak. (Hasan, 2009). Menjadi orang tua berarti mengasuh dan mendidik anak-anak Anda. Asuh berarti 
adalah kata yang memiliki makna dalam menjaga anak (merawat serta mendidik), membimbing (membantu serta melatih). Secara keseluruhan asuh menggambarkan semua dimensi perawatan, pemeliharaan serta dukungan keluarga (Djamarah, 2014)

Pola asuh merupakan pola interaksi yang terjadi antara orang tua dan anak. Hal tersebut meliputi pemenuhan dalam kebutuhan fisik dan non fisik. Kebutuhan fisik diantaranya makan dan minum sedangkan kebutuhan non fisik yaitu kasih sayang, empati dan perhatian, lainnya (Wibowo, 2012). Pengasuhan menggambarkan cerminan sikap maupun perilaku orang tua selama berinteraksi dengan anak. Selama kegiatan pengasuhan, maka setiap pengasuh dapat memberikan perhatian, aturan, disiplin, penghargaan atau hukuman serta memenuhi kemauan anak mereka. (Djamarah, 2014)

Orang tua meninggalkan rumah karena kesibukan pekerjaan sehingga peran pengasuhan anak digantikan oleh kakek dan nenek (grandparenting). Kembali ke zaman dahulu (kakek atau nenek) mengasuh anak mereka tentunya akan sangat jauh berbeda dengan ketika mereka mengasuh cucu. Hal ini dapat dipengaruhi oleh gaya hidup modern pada saat ini. Teknologi dan perkembangan ilmu pengetahuan terus berkembang setiap tahunnya. Namun, pada kenyataannya, justru banyak sekali orang tua yang menyerahkan hak asuh anaknya kepada kakek dan neneknya. Secara psikologis, kakek dan nenek akan memberikan perhatian secara penuh kepada cucu mereka. Namun, setiap kakek dan nenek akan mempunyai model pengasuhan yang berbeda. Hal ini dapat dipengaruhi oleh tingkat pendidikan, tingkat pengetahuan, aktivitas sehari-hari, kondisi sosial ekonomi, dll.

Pola asuh menjadi salah satu dari beberapa faktor penting untuk membentuk sebuah kepribadian pada anak. Apabila seseorang anak terlahir dari sebuah keluarga dengan pemikiran terbuka, toleransi, saling menghargai dan menerima setiap anggota keluarganya dengan baik, maka anak akan memiliki pemikiran terbuka, penuh inisiatif, percaya diri dan fleksibel saat tumbuh dan berkembang. Anak wajib dikembangkan sesuai dengan minatnya serta pribadinya, anak juga diberi kesempatan seluas-luasnya untuk mengoptimalkan bakat maupun talenta yang ada pada dirinya (Munandar, 2009).

Kepribadian (Personality) atau berarti kedok atau topeng. Dimana hal tersebut digunakan sebagai penutup muka yang sering digunakan oleh pemain panggung, sebagai gambaran perilaku maupun watak dari kepribadian orang. Hal tersebut sebagai ciri khas seseorang, baik itu sebuah kepribadian baik maupun yang kurang (Sjarkawi, 2006).

Kepribadian berkaitan dengan keseluruhan baik fikiran dan perasaan serta tingkah laku maupun kesadaran atau ketidaksadaran. Kepribadian dapat membimbing seseorang untuk dapat menyesuaikan dirinya terhadap lingkungan sosial maupun fisik. Seseorang harus sejak awal kehidupannya untuk dapat mengembangkan kepribadiannya dengan cara berupaya untuk mempertahankan keselarasan harmoni yang ada pada setiap elemen kepribadian (Alwisol, 2017).

Definisi lain memaparkan jika kepribadian ialah satu penggolongan perilaku dari seseorang yang ditampilkan maupun yang berbentuk potensi untuk menunjukkan suatu kekhasan dari seseorang. Jawaban atau respon terhadap stimulus merupakan definisi dari sebuah tingkah laku (Walgito, 1980).

Tidak ada salahnya diasuh oleh kakek-nenek karena kakek-nenek mengharapkan cucu (cucu) menjadi lebih baik, hanya saja pola asuh terkadang kurang baik. 6 tahun adalah waktu yang sensitif untuk menunjukkan kemampuan Anda. Pada saat seorang anak berusia 6 tahun, koneksi sarafnya bekerja dengan baik sehingga ia dapat memiliki koordinasi yang 
baik antara otak dan gerakannya, baik secara fisik maupun mental (Khadijah, 2016).

Berdasarkan observasi, ada tujuh kasus dimana orang tua mengalihkan peran orang tua kepada kakek atau nenek. Studi kasus di Kelurahan RT/007 RW/002 Dusun Besar, Kota Bengkulu memaparkan alasan menitipkan anaknya adalah karena sibuk bekerja dan pekerjaan yang tidak bisa ditinggalkan. Pekerjaan yang dilakukan orang tua ialah pekerjaan yang memerlukan ketekunan maupun ketelitian seperti birokrat, guru, pekerjaan swasta, polisi, petani dan pedagang. Dengan demikian, para orang tua terpaksa menitipkan anak mereka kepada kakek dan nenek dari mulai terbit matahari hingga petang atau sampai jam kerja para orang tua selesai. Hal tersebut dilakukan hampir setiap hari kecuali sedang cuti. Namun, hal tersebut juga tidak berlaku untuk keluarga dengan penghasilan menengah ke bawah karena tuntutan pekerjaan yang dilakukan setiap hari. Mengapa anak tidak diasuh oleh orang selain anggota keluarga karena faktor ekonomi dan fakta bahwa para orang tua tidak percaya jika anaknya dititipkan kepada orang selain saudara kandung.

Berdasarkan konteks di atas, Karena para peneliti tertarik pada banyak keluarga di masyarakat saat ini yang mengalihkan peran pengasuhan kepada kakek-nenek. Maka, penting bagi peneliti untuk melakukan penelitian dengan judul "Pola Asuh Grandparenting dalam Pembentukan Kepribadian Anak Usia 4-6 Tahun (Studi Kasus di Kelurahan RT/007 RW/002, Dusun Besar, Kota Bengkulu).

\section{Metode Penelitian}

Jenis penelitian yang digunakan ialah penelitian kualitatif dengan menggunakan pendekatan deskriptif kualitatif. Pengertian dari pendekatan deskriptif kualitatif ialah pendekatan yang digunakan dalam penelitian yang bertujuan untuk mengumpulkan informasi tentang suatu keadaan yang terjadi pada saat penelitian dilakukan. Penelitian kualitatif merpakan sebuah penelitian yang menggali fenomena dan mendeskripsikannya melalui bahasa dalam konteks yang alami. (Sugiyono, 2016).

Penelitian ini dilakukan di Kelurahan RT/007 RW/002, Dusun Besar, Kota Bengkulu. Jangka waktu penelitian adalah 16 Februari sampai dengan 27 Maret 2021. Sumber data yang digunakan adalah segala hal yang dapat memberikan konstribusi terkait informasi tentang data tersebut. Sumbernya dibedakan menjadi dua yaitu data primer dan sekunder. Pada penelitian ini, data utama berupa catatan wawancara dan observasi lapangan langsung yang dilakukan kepada 7 orang kakek dan 7 orang nenek yang merawat cucunya di Kelurahan RT/007 RW/002, Dusun Besar, Kota Bengkulu. Sedangkan. data sekunder diperoleh melalui cerita orang lain ataupun melalui dokumen.

Pada penelitian ini menggunakan lembar observasi untuk pengamatan, wawancara dan dokumentasi. Selanjutnya analisis data adalah proses penyederhanaan data kedalam bentuk yang lebih mudah dibaca dan dipahami. Adapun langkahlangkah dalam analisi data adalah: Reduksi data, Penyajian data, Conclusion Drawing/Verification, Triangulasi, dan Penarikan Kesimpulan.

\section{Hasil Penelitian dan Pembahasan}

Berdasarkan dari hasil dilapangan di Kelurahan RT/007 RW/002, Dusun Besar, Kota Bengkulu. Peneliti melaksanakan langkah selanjutnya yaitu melakukan analisis terhadap data yang diperoleh yaitu:

\section{Jenis - Jenis Pola Asuh:}

a. Pola Asuh Demokratis

Berdasarkan hasil temuan penelitian di RT/07 RW/02 kelurahan dusun besar kota bengkulu maka peneliti dapat menyimpulkan dari tujuh anggota keluarga yang mengalihan peran pengasuhan sementara kepada nenek 
empat keluarga yang mengunakan pola asuh demokratis yaitu keluarga ibu husni yeti, ibu meti herawati, ibu muhayah dan ibu widah sari. Dimana pola asuh yang memperhatikan dan menghargai kebebasan anak, namun kebebasan itu tidak mutlak nenek memberikan bimbingan yang penuh perhatian kepada anak.

Pola asuh ini memberikan kebebasan pada anak untuk mengemukakan pendapat, melakukan apa yang di inginkannya dengan tidak melewati batas-batas atau aturan-aturan yang telah di tetapkan bersama. Dalam pola asuh ini sikap terbuka antara nenek dengan anak. Mereka membuat aturanaturan yang telah disetujui bersama. Anak diberi kebebasan dan tangung jawab dalam mengutarakan pendapatnya, perasaan maupun keinginannya. Sehingga, pada pola asuh ini terlihat bahwa ada komunikasi yang baik diantara keduanya yaitu nenek dengan cucu.

Penjelasan terkait pola asuh demokratis di atas diperkuat oleh Janet Kay yang memaparkan pola asuh demokratis secara umum akan menunjukan tanggap terhadap anakanaknya dan ekpresi penuh cinta. Orang tua akan memperlihatkan kehangatan, peka terhadap setiap kebutuhan serta dapat mengembangkan pola komunikasi kepada anaknya secara baik sejak dini. Mereka mensupport anak terkait keinginan dan ambisinya. Batasan tekait perilaku mereka diskusikan bersama, disesuaikan serta diterapkan secara tegas namun tidak ada hukuman fisik. Pola asuh demokratis cenderung akan menghindari cara yang mengedepankan kekuasan dari orang tua sehingga anak tidak akan merasa tertekan. (Kay, 2013) Hal ini juga sesuai dari pendapat helmawati yang menjelaskan pola asuh demokratis meggunakan komunikasi dua arah, Suatu keputusan diambil bersama dengan mempertimbangkan kedua belah pihak. Anak diberi kebebasan dan bertanggung jawab terhadap yang dilakukannya (Helmawati, 2015).

\section{b. Pola Asuh Otoriter}

Berdasarkan hasil temuan di Kelurahan RT/007 RW/002, Dusun Besar, Kota Bengkulu, peneliti menarik kesimpulan bahwa tidak ada keluarga yang menggunakan pola asuh otoriter, dilihat dari nenek yang tidak menghadirkan pola asuh dengan kontrol yang terlalu ketat dan sedikit kehangatan untuk anak-anak mereka, juga mengikuti sesuatu sebagai aturan tanpa diskusi. Inilah sebabnya mengapa tingkah laku anak cenderung lebih penakut, seringkali tidak terlalu percaya diri, tidak jujur dan manja serta kurang proaktif.

Dari penjelasan terkait pola asuh otoriter di atas, hal tersebut diperkuat oleh pendapat Sudarwan Danim yang memaparkan bahwa pola asuh otoriter bertindak sesuai dengan aturannya artinya segala sesuatu yang menjadi aturan menjadi kewajiban yang wajib dipatuhi dan dilaksanakan oleh anak. Peraturan dilaksanakan secara kaku, kurang memahami dan mendengarkan anak serta tidak dijelaskan secara jelas kepada anak. Adanya control yang tinggi terhadap aturan dan kehanggatan antara orang tua dengan anak yang rendah ditunjukkan oleh pola asuh ini (Danim, 2010). Janet Kay juga menjelaskan pola asuh otoriter mempunyai batasan perilaku yang jelas namun dilakukan secara sepihak dengan tidak adanya proses diskusi diantara keduanya. Hukuman menjadi metode yang sering digunakan dan bahkan ada yang menggunakan metode lebih keras dan kasar. Pada pengasuhan ini, pengasuh lebih lambat tanggap dan 
hangat terhadap kebutuhan anak (Kay, 2013).

c. Pola Asuh Permisif

Berdasarkan hasil temuan di lapangan, peneliti dapat menarik kesimpulan bahwa dari tujuh keluarga yang mengalihkan sementara peran pengasuhannya kepada orang tua, ada tiga keluarga yang menggunakan pola asuh permisif, khususnya keluarga dari Ibu Remunah, Ibu Nur Hasanah dan Ibu Sukijah. Dalam pola asuh permisif, anak memiliki kendali dan kebebasan penuh untuk melakukan dan memutuskan sesuatu tanpa pertimbangan orang dewasa dalam hal ini kakek dan nenek. Pada pola asuh permisif, nenek akan lebih membebaskan anak tanpa perlu mengawasi dan berkomunikasi dengan anak tentang apa yang harus dilakukan atau diinginkan anak itu. Semua diperbolehkan atau dalam artian lain yaitu memanjakan anak. Pengawasan pada pengasuhan permisif sangat longgar yaitu memberikan kesempatan pada anak untuk melakukan sesuatu tanpa pengawasan yang memadai dari pihak mereka. Dalam pola asuh permisif ini, tidak ada yang memarahi atau memberikan peringatan kepada anak ketika ia dalam keadaan bahaya dan nasihat yang diberikan sangat sedikit.

Berdasarkan penjelasan pola asuh permisif di atas, hal ini sejalan dengan pandangan Al Tridhonanto yang menyatakan jika sifat dan sikap orang tua (wali) yang ramah, sehingga sering disukai anak sehingga orang tua harus mengikuti kemauan anak, baik mereka setuju atau tidak. Adapun strategi komunikasi yang diterapkan dalam pola ini adalah bahwa apa yang menjadi kemauan anak wajib dipatuhi dan diperbolehkan. Dalam pola asuh permisif, kepedulian ditunjukkan dengan memperbolehkan semua yang anak inginkan dan mendorong anak menjadi agresif serta rentan terhadap rasa tidak aman. Pola asuh ini adalah bahwa semua aturan dan tata tertib dalam keluarga berada di tangan anak (AlTridhonanto dan Agency, 2014).

Berdasarkan hasil kajian penelitian pola asuh permisif, dapat ditarik kesimpulan bahwa faktor-faktor yang mendukung penerapan pola asuh yang baik tidak hanya bergantung pada pola asuh yang diterapkan oleh kakek dan nenek, tetapi juga karakteristik dari seluruh lingkungan keluarga, baik faktor internal yang berasal dari anak itu sendiri maupun dari lingkungan eksternal anak.

\section{Tipe-Tipe Kepribadian}

a. Tipe Sanguin

Berdasarkan hasil penelitian di Kelurahan RT/007 RW/002, Dusun Besar, Kota Bengkulu, peneliti dapat menyimpulkan bahwa ada 3 anak memiliki kepribadian Sanguin yaitu: Kawah Abqori Agami, Mariyam Medina Hertawan dan Arjunah Giandra. Anak-anak memiliki kepribadian yang menyenangkan, anak-anak senang berbicara atau bercerita dengan teman sebaya maupun anggota keluarganya, sangat ingin tahu serta menikmati kegiatan yang spontan. Kelemahannya adalah ia cenderung berperilaku berdasarkan perasaan atau keinginannya, cepat marah atau emosional tidak stabil, gampang mengeluh serta perhatiannya yang mudah sekali teralihkan.

Dari penjelasan kepribadian sanguin di atas, hal itu didukung oleh pendapat dari Sjarkawi yang menerangkan bahwa seseorang dengan tipe sanguin mempunyai ciri-ciri diantaranya mempunyai gairah hidup, bersemangat, memiliki banyak kekuatan, dapat membuat lingkungan disekitarnya 
gembira dan senang. Untuk kelemahan dari tipe ini adalah bertindak sesuai emosinya atau keinginannya dan cendrung implusif. (Sjarkawi, 2006).

Penjelasan tersebut juga diperkuat oleh pendapat Hippocrates dan Galenus yang mengungkapkan bahwa orang yang memiliki kepribadian sanguin ini akan selalu menampilkan wajah yang berseri-seri, gembira, periang dan bersikap optimis. Untuk kelemahan ialah tipe ini merupakan orang yang bertindak sesuai keinginannya atau emosinya dan cenderung impulsive. (Supriyatin dkk., 2015).

b. Flegmatik

Hasil penelusuran di Kelurahan RT/007 RW/002, Dusun Besar, kota Bengkulu, peneliti memberi kesimpulan bahwa ada anak yang berkepribadian Flegmatik yaitu: Selta Meliani karena anak tersebut sering santai sehingga orang lain akan sering menganggapnya seorang pemalas. Hal itu bukan disebabkan mereka tidak cerdas, tetapi mereka lebih pintar dari anak-anak lain, mereka juga sangat mudah untuk berteman dengan teman sebayanya, juga sangat pandai menyembunyikan perasaannya, misalnya ketika mereka sedih (tertekan) atau senang. Ada kelemahannya yaitu anak cenderung pemalu, tidak suka keramaian, tidak banyak bicara, mudah cemas atau takut, egois, suka berpuas diri dan meremehkan hal-hal yang mudah, tidak mengerjakan yang sulit dilakukan.

Dari penjelasan kepribadian flegmatik di atas, hal tersebut didukung oleh pendapat Sjarkawi yaitu seseorang dengan tipe flegmatik akan memiliki ciri diantaranya tenang dan gejolak emosi tidak tampak sehingga naik atau turunnya emosi seseorang itu tidak terlihat secara jelas. Orang dengan tipe ini cenderung dapat mengontrol dirinya jauh lebih baik dan lebih introspektif. Ia juga mudah bergaul dengan orang lain, memiliki pembawaan yang santai dan mampu melihat serta memikirkan setiap permasalahan yang ada di sekitarnya. Mereka ialah seorang pengamat yang baik (Sjarkawi, 2006).

Pendapat tersebut diperkuat oleh pendapat S. Aminah dan Zulaika yaitu Individu dengan model flegmatik memiliki karakteristik yang sangat tenang, damai dan dapat mengontrol emosinya. Individu dengan kepribadian flegmatik akan cenderung cukup baik dalam mengontrol dirinya dan dapat menyelesaikan masalah yang ada (Ardiati, 2018). Tipe orang ini memiliki kelemahan, di antaranya adalah pribadi yang santai, tidak mau susah. malas dan juga terlihat lambat. Kelemahannya adalah mereka kurang rela mengorbankan diri demi orang lain dan cenderung begitu.

c. Melankolik

Hasil temuan di Kelurahan RT/007 RW/002, Dusun Besar, Kota Bengkulu, peneliti menarik kesimpulan bahwa di antara tujuh anak yang dibesarkan oleh neneknya, mereka tidak begitu rentan terhadap tipe ini. Pada tipe ini memiliki kelebihan diantaranya berhati-hati dalam bertindak, disiplin, menyukai hal-hal yang indah, perasaan kuat dan sensitif (sering murung). Kelemahannya adalah mudah terpengaruh emosi, lebih egois dan tidak terlalu peduli dengan temannya.

Dari penjelasan di atas, sejalan dengan pandangan Sjarkawi bahwa orang dengan tipe tersebut memiliki ciri-ciri yaitu berjiwa artistik dan cenderung menyukai keindahan, emosi kuat dan sangat sensitif (Sjarkawi, 2006). Menurut Littauer, kepribadian melankolis dicirikan sebagai perfeksionis (perfeksionis), serius dan pekerja keras, rentan terhadap 
kecemerlangan, berbakat dan kreatif, simpatik kepada orang lain, sangat berhati-hati, menghindari perhatian (Damayanti et al., 2017). Orang dengan tipe ini memiliki kelemahan dimana antara lain sangat mudah dikendalikan oleh emosinya dan cenderung menganggap bahwa perasaan yang mendasari dalam kehidupan sehariharinya adalah perasaan yang buruk.

\section{d. Tipe Kolerik}

Berdasarkan hasil temuan di Kelurahan RT/007 RW/002, Dusun Besar Kota Bengkulu, peneliti menarik kesimpulan bahwa ada dua anak yang memiliki kepribadian kolerik yaitu: Trisah Andini dan Sinta Nur Salsabilla. Sejak kecil sudah berbakat, ingin tahu besar dan semangat belajar tinggi, aktif, dan terbiasa disiplin seperti mengembalikan mainan ke tempat asalnya. Adapun kelemahan yang dimiliki ialah suka mengatur dan tidak sabaran, kurang peka terhadap perasaan orang lain, suka berpuas diri dan proaktif.

Berdasarkan pemaparan di atas, pendapat Sjarkawi sejalan dengan pendapat Sjarkawi bahwa tipe ini memiliki ciri-ciri seperti mandiri, disiplin, semangat belajar yang tinggi, semangat, memiliki banyak bakat dan memiliki jiwa seorang pemimpin. (Sjarkawi, 2006)

Penafsiran di atas juga sependapat dengan pendapat Sumadi bahwa tipe pemarah cenderung berorientasi pada tugas, disiplin, setia dan bertanggung jawab. (Chairilsyah, 2012) Orang dengan tipe ini memiliki kelemahan, antara lain sifat mementingkan diri sendiri, kurang mampu berempati dengan teman, kurang mampu mengembangkan rasa kasih sayang terhadap orang lain, dan tidak bisa diam.

e. Tipe Asertif
Berdasarkan hasil temuan di Kelurahan RT/007 RW/002 Dusun Besar, Kota Bengkulu, peneliti menarik kesimpulan bahwa terdapat satu orang anak yang berkepribadian arsetif yaitu Sofian Gusrada. Hal ini ditunjukkan dengan anak yang sudah dapat menyatakan pendapatnya sebelum maupun sesudah melakukan sesuatu, mereka juga memiliki perasaan yang sangat sensitif sehingga perkataannya tidak menyakiti hati orang lain, jujur dan pemaaf.

Berdasarkan penjelasan di atas, menurut Sjarkawi, tipe ini dicirikan antara lain mampu mengungkapkan pendapat, pandangan maupun gagasan secara konsisten, halus tetapi tidak merugikan orang lain. Tingkah laku mereka ialah tentang memperjuangkan hak pribadi tanpa mengabaikan maupun mengancam orang lain dengan melibatkan perasaan dan keyakinan orang lain. Dalam interaksinya dengan mereka, mereka mengungkapkan perasaan dan keyakinan mereka secara langsung, tepat terbuka, dan jujur (Sjarkawi, 2006). Karena tipe asertif merupakan tipe ideal, tidak banyak kelemahan yang bisa ditemukan.

\section{Simpulan dan Saran}

Berdasarkan hasil penelitian dapat ditarik kesimpulan tentang bagaimana kakek dan nenek membantu membentuk kepribadian anak usia 4-6 tahun di Kelurahan RT/007 RW/002, Dusun Besar, Kota Bengkulu:

1. Dari tujuh anggota keluarga, empat diantaranya menggunakan Pola asuh demokrasi dan tiga anggota keluarga mengadopsi pola asuh permisif.

2. Dari tujuh anggota keluarga, ada tiga anak dengan tipe kepribadian sanguin, satu dengan tipe kepribadian flegmatik, dua anak dengan kepribadian korelik dan satu dengan kepribadian asertif. 
Berdasarkan kesimpulan di atas, maka saran-saran peneliti sampaikan kepada:

1. Kakek-nenek harus lebih memperhatikan bagaimana menerapkan pola asuh yang tepat untuk membentuk kepribadian anak.

2. Kakek-nenek harus lebih dulu membatasi keinginan setiap anak dan melihat manfaatnya. Manfaat dari Menghukum anak ialah membuat mereka bertanggung jawab atas apa yang telah mereka lakukan tetapi menghukum tidak dengan hukuman fisik.

\section{DAFTAR PUSTAKA}

Adiwikarta, $\mathrm{S}$. Sosiologi (2016).

Analisis

$$
\text { Pendidikan: }
$$
Praksis Pendidikan.

Bandung: PT Remaja Rosdakarya.

Al-Tridhonanto, \& Agency, B. (2014). Mengembangkan Pola Asuh Demokratis. Jakarta: PT Gramedia.

Alwisol. (2017). Psikologi Kepribadian. Malang: UMM Press.

Ardiati, R. K. (2018). Peran orang tua dalam perkembangan kepribadian anak usia dini. SCHOULID: Indonesian Journal of School Counseling, 3(3), 7379. https://doi.org/10.23916/08413011

Chairilsyah, D. (2012).

Pembentukan Kepribadian Positif anak sejak usia dini. Educhild. Vol.01 No.1.

Dachlan, M. \& Dkk. (2019). Perkembangan Sosial Emosional Anak Usia Dini. Yogyakarta: CV Budi Utama.

Damayanti, H., Purwanti, P., \& Lestari, S. (2017). ANALISIS
PENYESUAIAN DIRI DITINJAU DARI TIPE KEPRIBADIAN PESERTA DIDIK KELAS $\mathrm{X}$ SMAN 1 PONTIANAK. Jurnal Pendidikan Dan Pembelajaran

Khatulistiwa, $6(11)$ https://jurnal.untan.ac.id/index.php/j pdpb/article/view/22729

Danim, S. (2010). Perkembangan Peserta Didik. Bandung: Alfabeta.

Djamarah, S. B. (2014). Pola Asuh Orang Tua dan Komunikasi dalam Keluarga. Jakarta: Rineka Cipta.

Hasan, M. (2009). Pendidikan Anak Usia Dini. Yogyakarta: Diva Press.

Helmawati. (2015). Pendidikan Keluarga. Bandung: Remaja Rosdakarya.

Kay, J. (2013). Pendidikan Anak Usia Dini. Yogyakarta: Kanisius.

Khadijah. (2016). Pengembangan Kognitif Anak Usia Dini. Medan: Perdana Publishing.

Menteri Pendidikan. (2003).

UndangUndang Republik Indonesia No. 20 Tahun 2003 tentang

Sistem Pendidikan Nasional (SISDIKNAS). Citra Umbara.

Mulyasa. (2017). Strategi Pembelajran PAUD. Jakarta: PT Remaja Rosdakarya.

Munandar, U. (2009).

Pengembangan Kreativitas Anak Berbakat. Jakarta:

Rineka Cipta.

Shochib, M. (2018). Pola Asuh Orang Tua Dalam Membentuk Anak Mengembangkan Disiplin Diri. Jakarta: PT Rineka Cipta. 
Sjarkawi. (2006). Pembentukan Kepribadian Anak. Jakarta: Bumi Aksara.

Sugiyono. (2016). Metode Penelitian Kuantitatif, Kualitatif dan $R \& D$. Bandung: Alfabeta.

Supriyatin, W., Rafsyam, Y., \& Febiana, N. (2015). APLIKASI ANDROID SEBAGAI MEDIA INFORMASI DALAM PENGENALAN KEPRIBADIAN ANAK USIA DINI. Orbith: Majalah Ilmiah Pengembangan Rekayasa Dan Sosial, 11(3), Article 3. https://doi.org/10.32497/orbith.v11i 3.325

Suyadi. (2014). Teori Pembelajaran Anak Usia Dini. Bandung: PT Remaja Rosdakarya.

Suyadi, \& Ulfah, M. (2015). Konsep Dasar PAUD. Bandung: PT Remaja Rosdakarya.

Umar, T., \& Sulo, L. (2000). Pengantar Pendidikan. Jakarta: PT Rineka Cipta.

Walgito, B. (1980). Pengantar Pisikologi Umum. Yogyakarta: CV Andi Offset.

Wibowo, A. (2012). Pendidikan Karakter. Yogyakarta: Pustaka Pelajar. 